Gitation: Jaramillo-Villanueva, J. L., Guerrero-Carrera, J., Vargas-López, S. \& Bustamante-González, A. (2021). Use of agricultural technology, yields and economic profitability of smallscale producers (Coffea arabica L.). Agro Productividad. https://doi.org/10.32854/ agrop.v14il1.1995

Editor in Chief: Dr. Jorge Cadena Iñiguez

Received: February 19, 2021. Accepted: October 23, 2021. Published on-line: November 26, 2021.

This work is licensed under a Creative Commons Attribution-NonCommercial 4.0 International license.

\section{Use of agricultural technology, yields and economic profitability of small-scale producers (Coffea arabica L.)}

\author{
Jaramillo-Villanueva, José Luis ${ }^{1 *}$; Guerrero-Carrera, Jesús ${ }^{1}$; Vargas-López, Samuel ${ }^{1}$; \\ Bustamante-González, Angel ${ }^{1}$ \\ 1 Colegio de Posgraduados. Campus Puebla. Avenida Forjadores 205, Momoxpan San Pedro Cholula, Puebla. \\ C.P. 72760 \\ *Correspondence: jaramillo@colpos.mx
}

\begin{abstract}
Objective: The objective of this study was to determine the relationship between use of agricultural technology and levels of crop yield and profitability of coffee farmers (Coffea arabica L.) en Puebal and Oaxaca, Mexico.

Design/Methodology/Approach: The field work was carried out in the Mazateca region of Oaxaca and the Cuetzalan region of Puebla, in 2019. The data were gathered by applying a survey, using a statistical sample, with $95 \%$ confidence and accuracy of $6 \%$ of the average coffee yields.

Results: The profitability (BCR) was 0.90, which means that for each invested peso, 0.10 pesos were lost, that is, $10 \%$ of the investment. For Puebla farmers, the RBC was 1.0 and for Oaxaca producers, 0.81 . The BCR of the producers that sold as parchment coffee was 1.16 for those from Cuetzalan and 1.04 for those from the Mazateca region. The group of producers that have high TUI have a different average yield and profitability than the average of the groups of producers that have medium and low TUI. The explanatory variables of yield and profitability are the TUI, the size of the PU, and human capital.

Study Limitations/Implications: This study, in a next stage, could benefit from estimating the rate of technology adoption and the training needs of coffee farmers.

Conclusions: Due to the positive effect of TUI and HC on yields and profitability, these can be part of public policy interventions to improve coffee growing.
\end{abstract}

Keywords: profitability, yields, coffee producers, use of technology.

\section{INTRODUCTION}

In Mexico, the coffee industry (Coffea arabica L.) is very important in social, environmental and economic terms; it is estimated that 515,000 producers participate in the production, of which $60 \%$ cultivate a hectare or less, $85 \%$ of the producers are indigenous people, located in 15 states (CEDRSSA, 2019). However, Chiapas, Veracruz, Puebla and Oaxaca contribute $87 \%$ of the surface harvested and $90 \%$ of the national production (SIAP, 2020). 
Compared to the environmental importance, Contreras-Hernández (2010) documented the environmental benefits of shade coffee: carbon capture, soil protection, recharge of water tables, and protection of biodiversity.

The primary production of coffee in Mexico is in crisis since 1992 and until today, period when there was a mean annual growth rate of $-4.27 \%$, explained by the fall in international prices and those paid to the producer; the latter were $41 \%$ lower in real terms in the period from 2015 to 2019, compared to the period of 1995 to 1999 (SIAP, 2020; Organización Internacional del Café, 2020).

Due to the fall in prices, the surface harvested also decreased, which went from 746,148 to 629,300 ha (reduction of $16 \%$ ). The production decreased from 1.98 to 0.90 million tons of cherry coffee (a reduction of 48\%). The fall in production is explained by the reduction in the unitary yields, which went from 2.65 ton/ha to 1.43 ton/ha, which represented a fall of $46 \%$ (SIAP, 2020). Under this scenario it is relevant to analyze the relationship between the use of technology, the yields and the profitability.

\section{Use of agricultural technology, production and profitability}

Technology, understood as a set of techniques that allow the practical use of scientific knowledge (Burgelman et al., 2008), means the practical application of scientific knowledge to create something new or to transform something that already exists. Productivity is the capacity of the production factors (land, work and capital) to generate goods and services in order to obtain benefits (Valbuena et al., 2018). In the agriculture and livestock sector, productivity is related to higher yields per surface unit. In this sense, Wambua et al. (2019) found that with greater use of agricultural technology, there is greater productivity and higher profitability of productive units.

Productivity is the main driver of the development process and represents half of the differences in the per capita gross domestic product among countries (Fuglie et al., 2020). The use of agricultural technology is positively related with higher profitability, mainly through greater production per surface unit and lower production costs (Espinosa-García et al., 2016). Therefore, researching the way that the use of technology generates greater productivity and profitability is a relevant task to improve the income of coffee producers. The hypothesis is that with higher technological level, there is higher yield and economic profitability. Based on this, the relationship between the use of agricultural technology in coffee production (Coffea arabica) and the levels of production, yields, and producers' profitability was determined with the purpose of generating information that contributes to improve the public interventions for coffee producers of Puebla and Oaxaca, Mexico.

\section{MATERIALS AND METHODS}

This study was conducted in the Mazateca region of Oaxaca and the Guetzalan region of Puebla, Mexico. The two regions are characterized by their dependency on coffee production as source of income and by their high socioeconomic and environmental vulnerability (Monterroso et al., 2014). Cuetzalan is located in the northeastern region of Puebla, where coffee production is the most important economic activity for small-scale producers (Rivadeneyra and Ramírez, 2006). The poverty levels in the eight municipalities 
that make up the region of Cuetzalan range from $70.2 \%$ to $93 \%$, which is why its income was below the minimum welfare line. The Mazateca region is located on the northeastern part of the state of Oaxaca; coffee production is the main source of income for the population, and has poverty levels between 74 and 98\% (CONEVAL, 2020).

The data were obtained through the application of a survey, using a statistical sample, with $95 \%$ confidence and accuracy of $6 \%$ of the mean of cherry coffee yields. The sample was $n=192$ producers. The distribution between both regions was proportional to the number of producers in each region. Applying the questionnaires was carried out in the first trimester of 2019. The information obtained was verified by key informants (technicians, technical coordinators, professors from the communities, and representative producers of social organizations). The questionnaire applied was made up of seven sections: social demographics, practices and technology, agriculture of the coffee crop, costs and income, sales prices, impacts and responses to the coffee crisis, climate events, and risk perception.

\section{Data analysis}

The relevant variables were the Benefit-Cost Ratio (BCR), the Technology Use Index (TUI), the Technical Assistance Index (TAI), the Human Capital (HC), the yields per hectare of cherry coffee, the production costs, and the income. The costs and the benefits were calculated for the BRC. The first are integrated by the costs of installation (fixed, variable and process). The benefits are the sales value, price received for the amount sold, whether cherry or parchment coffee.

The technological process that producers practice was made up of seven technological components: establishment of plant nursery, application of compost, fertilizer, pest/disease control, pruning, shade regulation, and grain processing. The TUI value for each producer resulted from dividing the number of technological components applied to the crop by the total technological components.

Four aspects were considered for the TAI, where producers received technical assistance services at least once during the productive cycle; elaboration and use of composts, fertilization, pest and disease control, and pruning. The producers who received technical assistance services in the four components were assigned a value of 1.0. For its part, the human capital was calcualted as the average of two components; years of schooling and number of training courses in coffee in the last three years. The weighing was $50 \%$ for each component.

\section{Analysis method: Benefit-Cost Ratio (BCR)}

To estimate the BCR, production costs were calculated, made up of installation costs (plantation) and operation costs. The first included soil preparation, cost of the plant material and workforce. The operation costs are paid each year and integrated by five concepts: fertilization, pest and disease control, weeding, pruning, harvest and transport. In addition, for producers that also conducted grain processing it also included the cost of depulping, washing, drying and cost of transport to the selling place. The benefit or income was the result of the amount sold multiplied by the market price. An Analysis of Variance (ANOVA) was used to identify the probable difference of the means of yield 
between groups of producers with different level of technology use. In order to explain the behavior of the unitary yield and of profitability, a multiple regression analysis was used, estimated by ordinary mean squares.

\section{RESULTS AND DISCUSSION}

The coffee producers were 57 years old on average, and had six years of schooling, equivalent to finished primary school. The number of members of a household was 3.6, nearly four members in Oaxaca and three in Puebla. These sociodemographic data are similar to those reported by INEGI (2020). The producers had much experience in both regions: 30 years in Cuetzalan and 24 years in the Mazateca. The average size of the plantations was 1.3 ha. In the region in Puebla, the plots were larger (1.6 ha) than in the region in Oaxaca (1.0 ha) (Table 1). In this regard, Espinoza-García et al. (2016) reported that the predominant size in the coffee producing regions is of less than 2 ha per producer.

The calculated household income was $\$ 47$ thousand MX pesos annually; $\$ 54$ thousand in the Cuetzalan region and $\$ 41$ thousand in the Mazateca. Converted into per capita income, it was $\$ 1645.0$ pesos in Cuetzalan and $\$ 1063.0$ in the Mazateca. CONEVAL (2020) reported the value of the food basket for March 2019 in $\$ 1,110.00$ pesos and of the food and non-food basket in $\$ 2012.0$ pesos.

These define the extreme poverty line from income and the poverty line from income, respectively. This reveals that, on average, all producers in the sample were considered as poor. Apodaca-González et al. (2020) reported poverty levels from income equivalent to those found in this study for households of coffee producers in Puebla.

The use of agricultural technology by coffee producers was generally low (0.60), higher for Cuetzalan (0.71) and lower for the Mazateca region (0.50). The access to technical assistance services was also low, with a value of 0.39. The producers from Cuetzalan had greater access (0.49) than producers from the Mazateca region (0.30), which could explain in part the lower yields per hectare in the Mazateca $\left(1316 \mathrm{~kg} \mathrm{ha}^{-1}\right)$ compared to Cuetzalan $\left(1805 \mathrm{~kg} \mathrm{ha}^{-1}\right)$. These results are consistent with official statistics (SIAP, 2020) and with

Table 1. Sociodemographic and technological characteristics of coffee producers.

\begin{tabular}{l|c|c|c|c|c|c}
\hline \multirow{2}{*}{ Variable } & \multicolumn{2}{c|}{ General } & \multicolumn{2}{c|}{ Cuetzalan } & \multicolumn{2}{c}{ Oaxaca } \\
\cline { 2 - 7 } & Mean & $\begin{array}{l}\text { Standard } \\
\text { deviation }\end{array}$ & Mean & $\begin{array}{l}\text { Standard } \\
\text { deviation }\end{array}$ & Mean & $\begin{array}{c}\text { Standard } \\
\text { deviation }\end{array}$ \\
\hline Age (years) & 57.1 & 13.8 & 60.7 & 11.7 & 54.0 & 14.8 \\
\hline Human capital & 0.55 & 0.29 & 0.62 & 0.37 & 0.44 & 0.36 \\
\hline Members & 3.6 & 1.8 & 3.2 & 1.5 & 3.8 & 2.0 \\
\hline Experience (years) & 26.5 & 10.7 & 29.6 & 15.3 & 23.9 & 13.7 \\
\hline Size (ha) & 1.31 & 0.7 & 1.6 & 1.2 & 1.0 & 0.8 \\
\hline Per capita income $(\$)$ & 1332.6 & 730.8 & 1645.0 & 833.3 & 1062.8 & 431.6 \\
\hline I.U.T & 0.60 & 0.22 & 0.71 & 0.26 & 0.50 & 0.20 \\
\hline I.A.T. & 0.39 & 0.21 & 0.51 & 0.19 & 0.28 & 0.17 \\
\hline Yields $\left(\mathrm{kg} \mathrm{ha}^{-1}\right)$ & 1542.5 & 619.2 & 1804.8 & 410.4 & 1315.8 & 268.0 \\
\hline
\end{tabular}


what was reported by Canet et al. (2016), who showed a decrease in the yields, both in Puebla and in Oaxaca since 1990 until today.

\section{Costs and profitability of coffee production}

The production cost of cherry coffee is integrated by installation costs and operation costs. Within the operation costs, the cost of workforce represented $70 \%$, which shows the social importance of this activity. From the total of workforce between, between 30 and $60 \%$ was family members, depending on the size of the plantation. In general, the costs were higher for Cuetzalan, derived from the greater use of technological components. The general profitability (BCR) was 0.90, which means that for each peso invested, 0.10 pesos were lost; that is, $10 \%$ of the investment. For producers in Puebla, the BCR was 1.0 and for those in Oaxaca, 0.81 (Table 2). In previous studies, negative profitability was reported for small-scale producers in Hawaii (Woodill et al., 2014) and for producers in Brazil (Turco et al., 2017), while Espinosa-García et al. (2016) reported for Mexico that yields under 4.5 tons per hectare generate negative profitability.

The producers, once the cherry coffee production has been harvested, have the options of selling the coffee as cherry or processing it (depulping, washing and drying). Of the producers, $65 \%$ processed and sold parchment coffee, the rest sold it as cherry. The BCR of the producers that sold parchment was 1.16 for those in Guetzalan and 1.04 for those in the Mazateca. The increase in profitability that producers who sold parchment obtained is the result of the added value from processing.

Table 2. Costs and income of coffee productionin Oaxaca and Puebla, Mexico.

\begin{tabular}{|c|c|c|c|c|c|c|}
\hline Instalatión costs $(\$)$ & Average & $\begin{array}{l}\text { Standard } \\
\text { deviation }\end{array}$ & $\begin{array}{l}\text { Mean } \\
\text { Puebla }\end{array}$ & $\begin{array}{l}\text { Standard } \\
\text { deviation }\end{array}$ & $\begin{array}{c}\text { Mean } \\
\text { Oaxaca }\end{array}$ & $\begin{array}{l}\text { Standard } \\
\text { deviation }\end{array}$ \\
\hline Tillage costs & 3789.8 & 3109.2 & 4483.1 & 3669.0 & 3190.8 & 2388.8 \\
\hline Coffee plant & 15159.4 & 12436.7 & 17932.6 & 14675.9 & 12763.1 & 9555.2 \\
\hline Labour costs & 6316.4 & 5182.0 & 7471.9 & 6115.0 & 5318.0 & 3981.3 \\
\hline Instalation & 25265.6 & 20727.8 & 29887.6 & 24459.8 & 21271.8 & 15925.3 \\
\hline \multicolumn{7}{|l|}{ Operation costs } \\
\hline Costs of fertilizer & 1574.3 & 2423.1 & 2583.7 & 2670.4 & 702.0 & 1784.5 \\
\hline Pests and diseases & 1232.0 & 2424.9 & 2090.6 & 3152.6 & 490.1 & 1112.2 \\
\hline Cleaning & 1779.5 & 1254.0 & 2083.7 & 1519.7 & 1516.7 & 895.3 \\
\hline Pruning & 430.9 & 663.1 & 672.6 & 839.1 & 222.0 & 347.5 \\
\hline Harvest & 6887.4 & 5172.1 & 7290.7 & 6063.7 & 6538.9 & 4255.2 \\
\hline Transportation & 909.9 & 1327.7 & 974.4 & 1563.5 & 854.2 & 1088.8 \\
\hline Total operation costs & 12814.0 & 13264.9 & 15695.7 & 15809.0 & 10324.0 & 9483.5 \\
\hline Fixed costs & 2127.8 & 1748.8 & 2441.1 & 1960.8 & 1857.1 & 1500.1 \\
\hline Production costs & 14911.5 & 10083.0 & 18089.7 & 11641.3 & 12165.3 & 7551.6 \\
\hline Income (cherry) & 13443.20 & 8672.71 & 18124.2 & 8299.91 & 9898.65 & 4891.21 \\
\hline BCR (cherry) & 0.90 & & 1.0 & & 0.81 & \\
\hline
\end{tabular}




\section{Level of use of technology and yields}

The level of use of technology in the coffee production process is a factor that is fostered to improve the unitary yields, and in the case of fixed prices, also to improve the profitability. The analysis of variance revealed that the level of use of technology, represented by the "low" and "medium" Technological Index (TUI) belong to the same group, which means that the group of producers with "low" TI and "medium" TI have a mean of coffee yield (ton/ha) that is statistically equal. Instead, "low" TUI and "high" TUI have different means (Table 3). Similarly, the "medium" and "high" TUIs are significant, which is why they are in different groups, and their means are different. The behavior of the groups with "low" and "medium" level of use of technology also have an equal profitability mean (BCR). Meanwhile, the "low" and "high", and "medium" and "high" groups also have different means. These results are consistent with what is reported by Wambua et al. (2019) for coffee producers in Kenya and by Afolami et al. (2015) for producers in Nigeria.

\section{Explicative model of the yields and the profitability}

The coffee yield $\left(\mathrm{t} \mathrm{ha}^{-1}\right)$ and the profitability (BCR), according to the results presented, are related variables. The results from the statistical model show that the TI and the size of the PU are the most important explicative variables both of the yield and of the profitability (Table 4). In the case of the yields, the "region" variable is very important and significant $(p>0.05)$. In the case of the explanation of the profitability, the "schooling" variable is the third most important. The size of the plot of the PU, the TUI and the HC are variables that are susceptible of being modified to improve the yields and the profitability, especially the last two. The positive effect of agricultural technology on yield and profitability was reported by Wambua et al. (2019) in a study in Kenya. Xu et al. (2009) reported, in a study in Zambia, that schooling had a positive effect on the profitability, and Bravo-Monroy et al. (2016) found that with larger size of the population the net profit of coffee producers in Colombia will be affected positively.

Table 3. Difference of the means of yield (ton/ha) and profitability (BCR) according to the level of use of technology.

\begin{tabular}{l|l|c|c|c}
\hline \multicolumn{2}{c|}{ Yield (kg/ha) } & $\begin{array}{c}\text { Means } \\
\text { difference }\end{array}$ & E.T & Significance \\
\hline \multirow{2}{*}{ IT Low } & Medium & $\mathbf{- 9 2 . 5 1}$ & $\mathbf{7 1 . 9 3}$ & $\mathbf{0 . 4 3 9}$ \\
\cline { 2 - 5 } & Higth & $-468.06^{*}$ & 66.97 & 0.000 \\
\hline \multirow{2}{*}{ IT Medium } & Low & $\mathbf{9 2 . 5 1}$ & $\mathbf{7 1 . 9 3}$ & $\mathbf{0 . 4 3 9}$ \\
\cline { 2 - 5 } & Higth & $-375.55^{*}$ & 61.21 & 0.000 \\
\hline Profitability (cherry) & \multicolumn{5}{|c}{} \\
\hline IT Low & Medium & $\mathbf{- 0 . 0 8 4}$ & $\mathbf{0 . 0 4 6}$ & $\mathbf{0 . 1 8 4}$ \\
\cline { 2 - 5 } & Higth & $-0.404 *$ & 0.042 & 0.000 \\
\hline IT medium & Low & $\mathbf{0 . 0 8 4}$ & $\mathbf{0 . 0 4 6}$ & $\mathbf{0 . 1 8 4}$ \\
\cline { 2 - 5 } & Higth & $-0.319 *$ & 0.039 & 0.000 \\
\hline
\end{tabular}


Table 4. Explicative model of the yields and the profitability.

\begin{tabular}{|c|c|c|c|c|c|c|}
\hline \multirow[b]{2}{*}{ Explicative variable } & \multicolumn{3}{|c|}{ Yields } & \multicolumn{3}{|c|}{ Profitability } \\
\hline & coefficient & $\begin{array}{c}\text { Typical } \\
\text { error }\end{array}$ & t-value & coefficient & $\begin{array}{c}\text { Typical } \\
\text { error }\end{array}$ & t-value \\
\hline (Constant) & 0.10 & 118.13 & 5.69 & .432 & .082 & 5.25 \\
\hline Region & .369 & 41.98 & 7.48 & .091 & .022 & 2.37 \\
\hline Members & .064 & 10.66 & 1.39 & .012 & .007 & 0.25 \\
\hline Age (years) & -.064 & 37.58 & -1.29 & -.059 & .026 & -1.17 \\
\hline Human capital & .134 & 6.26 & 2.36 & .188 & .004 & 3.27 \\
\hline Experience (years) & .109 & 1.49 & 2.12 & .007 & .001 & 0.14 \\
\hline Size (Ha) & .383 & 22.14 & 7.03 & .576 & .015 & 10.46 \\
\hline IUT & .305 & 79.66 & 5.66 & .389 & .056 & 7.14 \\
\hline A.T. Index & .043 & 82.84 & 0.72 & -.056 & .058 & -0.92 \\
\hline Income $(\$)$ & .063 & 0.02 & 1.25 & .053 & .012 & 1.04 \\
\hline $\operatorname{Adjust}\left(\mathrm{R}^{2} / \mathrm{R}^{2}\right.$ ajust $)$ & \multicolumn{3}{|c|}{$0.715 / 0.701$} & \multicolumn{3}{|c|}{$0.690 / 0.684$} \\
\hline F-statistic & \multicolumn{3}{|c|}{49.47} & \multicolumn{3}{|c|}{47.98} \\
\hline $\mathrm{S}-\mathrm{W}($ prob $>\mathrm{z})$ & \multicolumn{3}{|c|}{0.1674} & \multicolumn{3}{|c|}{0.1651} \\
\hline
\end{tabular}

Regarding the goodness of fit of the models, taking together the independent variables, they explain $71 \%$ of the behavior of the yields and $69 \%$ of the profitability. The values of the $\mathrm{F}$ statistics reject the null hypothesis that the population value of $\mathrm{R}^{2}$ is zero. Therefore, there is a significant linear relation $(p>0.05)$.

\section{GONGLUSIONS}

Coffee producers, especially those with less surface, face an adverse situation in the productive and in the economic aspects. The coffee yields in 2019 were lower than in the 1990s, and than those from the first decade of this century; as consequence, the profitability is negative in most of the sites and producers surveyed. The level of use of agricultural technology in coffee production is limited, although it shows a positive effect in improving yields and profitability. The factors that explain the behavior of the yields and of the profitability are mainly level of use of technology, size of the production unit, and human capital. These variables could be part of a public support strategy to improve the yields and the profitability of the aromatic plant.

\section{ACKNOWLEDGEMENTS}

We thank the coffee producers of Puebla and Oaxaca for the logistical assistance for the field work.

\section{REFERENGES}

Afolami, C.A., Obayelu, A.E., \& Vaughan, I.I. (2015). Welfare impact of adoption of improved cassava varieties by rural households in South Western Nigeria. Agricultural and Food Economics, 3(18):1-17. https://doi. org/10.1186/s40100-015-0037-2.

Apodaca-González, G., Juárez-Sánchez, J. P., Ramírez-Valverde, B., Díaz-Ruiz, R., Rodríguez-Escobedo, F., \& Vázquez-Solís, V. (2020). La alimentación familiar de pequeños productores de café y variabilidad 
climática en Huehuetla, Puebla, México. Agricultura Sociedad Y Desarrollo, 17(2):375-396. https://doi. org/10.22231/asyd.v17i2.1350.

Bravo-Monroy, L., Potts, S.G., \& Tzanopoulos, J. (2016). Drivers influencing farmer decisions for adopting organic or conventional coffee management practices. Food policy, 58: 49-61. https://doi.org/10.1016/j. foodpol.2015.11.003.

Burgelman, R.A., Christensen, G.M., \& Wheelwright, S.C. (2008). Strategic management of technology and innovation. Ed. McGraw-Hill/Irwin, 5th Edition, ISBN-13: 978-0073381541. 1280 p.

Canet, B.G., Soto V.C., Ocampo, T.P., Rivera, R.J., Navarro, H.A., Guatemala, M.G., \& Villanueva R.S. (2016). La situación y tendencias de la producción de café en América Latina y El Caribe. Publicación No. IICA P311. 126 p.

Centro de Estudios para el Desarrollo Rural Sustentable y la Soberanía Alimentaria (CEDRSSA). (2019). Caracterización de los sistemas alimentarios de los pueblos indígenas de México. http://www.cedrssa. gob.mx/

Consejo Nacional de Evaluación de la Política de Desarrollo Social (CONEVAL). (2020). Evolución de las líneas de pobreza por ingresos. Disponible en: https://www.coneval.org.mx/Medicion/MP/Paginas/ Lineas-de-bienestar-y-canasta-basica.aspx

Contreras-Hernández, A. (2010). Los cafetales de Veracruz y su contribución a la sustentabilidad. Revista Estudios Agrarios, 45, 143-citation_lastpage.

Espinosa-García,J. A., Uresti-Gil,J., Vélez-Izquierdo, A., Moctezuma-López, G., Uresti-Durán, D., GóngoraGonzález, S. F., \& Inurreta-Aguirre, H. D. (2016). Productividad y rentabilidad potencial del café (Coffea arabica L.) en el trópico mexicano. Revista Mexicana de Ciencias Agrícolas, 7(8), 2011-2024. http:// www.scielo.org.mx/scielo.php?script=sci_arttext\&pid=S2007-09342016000802011\&lng=es\&tlng=es.

Fuglie, K., Dhehibi, B., El Shahat, A. A. I., \& Aw Hassan, A. (2020). Water, Policy, and Productivity in Egyptian Agriculture. American Journal of Agricultural Economics. https://doi.org/10.1111/ajae.12148

Instituto Nacional de Estadística y Geografía (INEGI). (2020). Censo de Población y Vivienda. https://www. inegi.org.mx/programas/ccpv/2020/

Monterroso, A., Gonde, G., Gay, C., Gómez, D., \& López, J. (2014). Two methods to assess vulnerability to climate change in the Mexican agricultural sector. Mitig Adapt Strateg Glob Change: 19:445-461. https:// doi.org/10.1007/s1 1027-012-9442-y

Organización Internacional del Café (OIC). (2020). Informe del mercado de café. http://www.ico.org/es/ Council-20-21-c.asp

Rivadeneyra, P. J. I. \& Ramírez, V. B. (2006). El comercio local del café a raíz de su crisis en Sierra Norte de Puebla. Revista Mexicana de Agronegocios, 10(18):1-14. https://www.redalyc.org/articulo.oa?id=14101807

Servicio de Información Agroalimentaria y Pesquera (SIAP). (2020). Siembra y Cosechas. http://infosiap.siap. gob.mx:8080/agricola_siap_gobmx/ResumenProducto.do

Turco, P.H.N., Esperancini, M.S.T., Bueno, O.D.G., \& Oliveira, M.D.M. (2017). Economic profitability in conventional and irrigated coffee production systems in three municipalities in the Marilia region of Sao Paulo, Brazil. Ciência Rural, 47(11). http://dx.doi.org/10.1590/0103-8478cr20170170

Valbuena, D.N.J., Leal, G.M., \& Urdaneta, M.A. (2018). ADN organizacional y productividad en las empresas familiares. Desarrollo Gerencial, 10(1):105-122. https://doi.org/10.17081/dege.10.1.2987

Wambua, D.M., Ndirangu, S.N., Njeru, L.K., \& Gichimu, B.M. (2019). Effects of recommended improved crop technologies and socio-economic factors on coffee profitability among smallholder farmers in Embu County, Kenya. African Journal of Agricultural Research, 14(34): 1957-1966.

Woodill, A.J., Hemachandra, D., Nakamoto, S.T., \& Leung, P. (2014). The economics of coffee production in Hawai ‘i. Econ, EI 25:1-9.

Xu, Z., Guan, Z., Jayne, T.S., \& Black, R. (2009). Factors influencing the profitability of fertilizer use on maize in Zambia. Agricultural Economics, 4O(4): 437-446. https://doi.org/10.1111/j.1574-0862.2009.00384.x 